\title{
Pengelolaan Sampah Berbasis “Zero Waste” Skala Rumah Tangga Secara Mandiri
}

\author{
Ika Wahyuning Widiarti \\ Program Studi Teknik Lingkungan Fakultas Teknologi Mineral \\ Universitas Pembangunan "Veteran” Yogyakarta \\ e-mail: ika_wah84@yahoo.co.id
}

\begin{abstract}
Abstrak
Pengelolaan secara zero waste merupakan pengelolaan dengan melakukan pemilahan, pengomposan dan pengumpulan barang layak jual. Pemilahan sampah dalam rumah tangga harus didukung fasilitas pewadahan berupa tong sampah yang memadai. Tong sampah yang harus disediakan dalam rumah cukup dibagi untuk 2 jenis sampah yaitu sampah organik (basah) dan sampah anorganik (kering). Sampah yang telah terpilah menjadi sampah basah dan kering selanjutnya dilakukan pengelolaan yaitu pengomposan dan pengumpulan sampah layak jual. Pengomposan merupakan teknik untuk mengolah sampah organik yang berupa sampah sisa makanan, sisa potongan sayur dan buah atau sampah dapur dan sampah dari sapuan halaman rumah. Jika sampah organik rumah tangga dikelola secara mandiri (on site) dengan cara dikomposkan maka sampah anorganik harus dikelola dengan bantuan pihak ketiga (off site). Pihak ketiga yang dapat mendukung pengelolaan sampah anorganik rumah tangga adalah para pelaku usaha daur ulang informal antara lain pemulung, tukang loak, pengrajin produk daur ulang khusus untuk sampah plastik kemasan berlapis aluminium foil serta ada alternatif baru yaitu menabung sampah di bank sampah.
\end{abstract}

Kata kunci: pengelolaan sampah, zero waste, sampah, rumah tangga

\section{Pendahuluan}

Meningkatnya jumlah sampah saat ini disebabkan oleh tingkat populasi dan standar gaya hidup, yaitu semakin maju dan sejahtera kehidupan seseorang maka semakin tinggi jumlah sampah yang dihasilkan (El Haggar, 2007). Peningkatan jumlah sampah terjadi seiring deret ukur sedangkan ketersedian lahan Tempat Pembuangan Akhir (TPA) sampah mengikuti deret hitung. Hal ini mengakibatkan lahan TPA memiliki umur yang pendek karena tidak mampu lagi menampung sampah yang ada. Rendahnya teknologi yang dimiliki dan lemahnya infrastruktur menimbulkan permasalahan sampah yang cukup rumit terutama di negara berkembang seperti Indonesia. Pemerintah selaku stakeholder mempunyai kewajiban untuk menerapkan sistem pengelolaan sampah yang efektif dalam mengatasi permasalahan sampah. Selain itu, peran serta masyarakat juga diharapkan dapat membantu mengatasi masalah tersebut karena kurangnya kesadaran masyarakat terhadap masalah akibat keberadaan sampah mempunyai andil besar dalam memperburuk tata kelola sampah.

Konsep pengelolaan sampah 3R sudah tidak asing lagi di telinga masyarakat. Konsep ini sangat cocok diterapkan di negara berkembang yang karena keterbatasan teknologi maka harus memberdayakan masyarakat sebagai pelaku yang menghasilkan sampah. Namun, pada 
kenyataannya penerapan 3R dalam kehidupan sehari-hari masih jauh dari yang diharapkan. Prinsip Reduce, Reuse, Recycle (3R) yang menjadi ujung tombak dalam menangani sampah di lingkungan masyarakat seakan hanya slogan yang tidak mengena.

Sampah adalah barang atau benda yang telah habis nilai manfaatnya. Definisi ini menimbulkan kesan negatif yang menjadikan sampah dipandang sebagai benda yang harus segera disingkirkan dari halaman rumah apapun caranya. Tentu paradigma tentang pengertian sampah ini harus diubah agar masyarakat memiliki kesadaran untuk mengelola sampahnya masing-masing sehingga permasalahan lingkungan karena sampah dapat terminimalisir. Kholil (2004) dalam Saribanon (2009) mengemukakan bahwa pengelolaan sampah di masa yang akan datang perlu lebih dititikberatkan pada perubahan cara pandang dan perilaku masyarakat dan lebih mengutamakan keterlibatan masyarakat dalam pengelolaannya (bottom-up) sebab terbukti pendekatan yang bersifat top-down tidak berjalan secara efektif.

Perubahan cara pandang masyarakat terhadap sampah sudah terjadi di beberapa wilayah di Yogyakarta seperti dusun Sukunan, Kelajuran dan beberapa daerah lainnya. Dusun Sukunan, misalnya, warga di wilayah tersebut melakukan pengelolaan sampah secara komunal dengan menerapkan prinsip 3R. Sampah dipilah di masing-masing rumah lalu diangkut dan dikumpulkan pada Tempat Pembuangan Sementara (TPS) yang dibangun secara mandiri. Kemudian setelah sampah terkumpul, sebagian sampah dijual dan sebagian lainnya didaur ulang menjadi produk bermanfaat atau kerajinan. Pemberdayaan masyarakat dalam mengelola sampah ini ternyata mampu mengurangi jumlah sampah yang harus dibuang ke TPA Piyungan secara signifikan. Selain itu, meningkatkan pendapatan masyarakat karena penjualan produk daur ulang yang dihasilkan. Kesadaran lingkungan dan peran aktif masyarakat ini dapat muncul karena pemahaman baru yang positif mengenai sampah. Pemahaman baru tersebut adalah bahwa sampah merupakan barang sisa yang memiliki manfaat lain secara ekonomi melalui pemilahan dan proses daur ulang.

Pemberdayaan masyarakat dalam mengelola sampah secara komunal tidak selalu berjalan mulus. Konflik kepentingan masih menjadi masalah utama dalam pengelolaan sampah secara komunal. Pandangan bahwa dengan membayar retribusi tanpa harus repot-repot mengelola sampah sudah cukup dianggap sebagai peran serta masyarakat dalam mengatasi sampah juga menjadi salah faktor munculnya konflik ini. Konflik sosial seperti ini seringkali menghambat langkah aktif yang telah muncul pada segelintir warga. Padahal semangat untuk mengelola sampah tidak boleh sirna hanya karena adanya konflik tersebut. Solusi untuk mengatasi masalah ini adalah pengelolaan sampah secara mandiri pada skala rumah tangga. Pengelolaan sampah skala rumah tangga dapat dilakukan dengan konsep zero waste. 
Prinsip nol sampah atau zero waste merupakan konsep pengelolaan sampah yang didasarkan pada kegiatan daur ulang (Recycle). Pengelolaan sampah dilakukan dengan melakukan pemilahan, pengomposan dan pengumpulan barang layak jual (Ika, 2000). Menurut Maharani, dkk (2007), penggunaan kembali, minimalisasi, dan daur ulang sampah adalah hal yang sangat perlu dilakukan untuk mengurangi timbulan sampah yang membebani TPA dan lingkungan. Jika memungkinkan, 3R dilakukan sejak dari sumber timbulan sampah sehingga terjadi minimalisasi sampah yang diangkut menuju TPA. Konsep daur ulang dan pengomposan sampah ini mampu mereduksi timbulan sampah yang terangkut ke TPS/TPA di Kelurahan Kebonmanis, Cilacap sebesar 75\%, yaitu dari 23,638 m3/hari menjadi 5,821 m3/hari (Ika, 2000).

Zero waste pada dasarnya bukanlah pengelolaan hingga tidak ada lagi sampah yang dihasilkan karena tidak ada aktivitas manusia yang tidak menghasilkan sampah. Namun, konsep ini menekankan pada upaya pengurangan hingga nol jumlah sampah yang masuk ke TPA. Oleh karena itu, dalam makalah ini akan mengkaji pengelolaan sampah pada skala rumah tangga berdasarkan konsep zero waste.

\section{Metode Penelitian}

Metode penulisan yang dipakai dalam makalah ini adalah metode deskriptif analitis yaitu:

a. Mengidentifikasi permasalahan berdasarkan data dan fakta yang ada,

b. Menganalisis permasalahan berdasarkan pustaka dan data pendukung yang lain,

c. Mencari alternatif pemecahan masalah, yaitu memberikan deskripsi upaya pengelolaan sampah rumah pada skala rumah tangga.

Data yang digunakan adalah data sekunder yang bersumber dari jurnal ilmiah, buku teks dan pendukung lain yang berkaitan. Data makalah ini dikumpulkan dari dari jurnal ilmiah, buku teks dan pendukung lain yang saling berkaitan.

\section{Hasil dan Pembahasan}

\section{a) Potensi Sampah yang Dihasilkan dalam Rumah Tangga}

Rumah tangga merupakan komponen terkecil dari sumber penghasil sampah yang ada pada suatu wilayah jika dilihat dari volumenya. Timbulan sampah yang dihasilkan dalam rumah tangga dihitung berdasarkan jumlah anggota yang ada. Pada umumnya, satu rumah tangga dapat terdiri dari 3-6 anggota keluarga. Jika setiap orang menghasilkan sampah 2,5 liter/orang hari atau 0,5 kg/orang hari (Surbakti, 2009) maka setiap rumah menghasilkan sampah 7,5-15 liter/hari atau 1,5-3 kg/hari. 
Pada umumnya, sampah yang dihasilkan dalam rumah tangga meliputi sampah organik, anorganik dan sampah B3 (Bahan Beracun dan Berbahaya). Komponen sampah yang sering dihasilkan dalam rumah tangga disajikan dalam Tabel 1.

Tabel 1. Sampah yang dihasilkan dalam Rumah Tangga

\begin{tabular}{|l|l|l|}
\hline \multicolumn{1}{|c|}{ Sampah Organik } & \multicolumn{1}{|c|}{ Sampah Anorganik } & \multicolumn{1}{c|}{ Sampah B3 } \\
\hline Sisa makanan & Kertas Koran & Batu batere; \\
Sisa potongan sayur dan buah & Kertas HVS putih & Lampu bohlam dan Neon; \\
Sampah sapuan halaman & Kardus coklat & Wadah kemasan pembersih lantai; \\
& kertas karton & dll \\
& potongan kertas berwarna & \\
& Plastik kresek & \\
& Botol plastik & \\
& Logam & \\
& Botol kaca & \\
& Kain & \\
& dll & \\
\hline
\end{tabular}

Sampah organik memiliki komposisi paling besar yaitu 70\% daripada sampah anorganik yaitu 28\% dan sampah B3 yang hanya 2\% (Lya, 2009). Sampah organik yang dihasilkan secara umum hanya 3 jenis yaitu sampah sisa makanan, sisa potongan sayur dan buah atau sampah dapur dan sampah dari sapuan halaman rumah.

Sampah anorganik jenisnya sangat beragam yaitu kertas, plastik, besi, kaca dan kain. Dari jenis ini masing-masing juga memiliki kategori yang bermacam-macam contohnya kertas. Kertas dapat meliputi kertas HVS putih, buram, kertas karton, kardus, kertas berwarna (misal: brosur/leaflet). Begitu juga dengan plastik dapat dibedakan contohnya yaitu plastik kresek, botol plastik dengan jenis plastik yang berbeda-beda. Untuk sampah B3, yang sering dihasilkan dalam rumah tangga adalah lampu bohlam/neon dan batu baterai.

Keberagaman sampah yang dihasilkan tentu akan menimbulkan permasalahan jika pembuangan sampah dilakukan hanya dengan membuang ke TPA karena keterbatasan kapasitas. Bahkan mungkin terjadi sampah tersebut akan dibuang ke Tempat Pembuangan Sementara (TPS) liar sehingga menimbulkan pencemaran lingkungan. Oleh karena itu, sangat diperlukan teknik pengelolaan sampah yang mengurangi volume sampah ke TPA.

\section{b) Pengelolaan Sampah dalam Rumah Tangga}

\section{- Pemilahan Sampah}

Pengelolaan secara zero waste merupakan pengelolaan dengan melakukan pemilahan, pengomposan dan pengumpulan barang layak jual (Ika, 2000). Hal ini dimaksudkan supaya jumlah sampah yang 
masuk ke TPA seminimal mungkin bahkan hingga nol sampah. Berdasarkan konsep tersebut maka hal dilakukan pertama kali adalah pemilahan.

Pemilahan dalam rumah tangga harus didukung fasilitas pewadahan berupa tong sampah yang memadai. Selain itu, pemahaman mengenai pentingnya memilah sampah harus didukung oleh seluruh anggota keluarga sehingga kegiatan ini dapat berjalan dengan baik. Pemilahan diawal ketika sampah timbul memudahkan proses pengelolaan sampah. Tong sampah yang harus disediakan dalam rumah cukup dibagi untuk 2 jenis sampah yaitu sampah organik (basah) dan sampah anorganik (kering). Selain itu, kebutuhan tong sampah untuk mendukung pemilahan juga perlu diperhatikan.

Kebutuhan tong sampah tergantung pada gaya hidup dalam keluarga dan kondisi rumah. Jika rumah memiliki halaman yang luas dan banyak ditumbuhi tanaman maka perlu disediakan tong untuk sampah organik sapuan halaman yang cukup besar dan tong sampah anorganik kecil. Untuk di dalam rumah seperti ruang tamu, ruang keluarga dan kamar tidur cukup disediakan tong sampah anorganik (kering). Sedangkan dapur disediakan tong sampah organik (basah) dan tong sampah anorganik (kering). Tong sampah organik yang disediakan sebaiknya memiliki ukuran yang cukup besar karena di dapur akan banyak dihasilkan sampah sisa makanan dan sisa potongan sayuran dan buah. Selain itu, tong sampah ini sebagai sentra pembuangan sampah organik yang mungkin timbul dari ruang tamu, ruang keluarga dan kamar tidur. Hal ini dikarenakan aktivitas anggota keluarga di ruang manapun memungkinkan untuk menghasilkan sampah organik.

\section{- Pengomposan Sampah Organik}

Sampah yang telah terpilah menjadi sampah basah dan kering selanjutnya dilakukan pengelolaan yaitu pengomposan dan pengumpulan sampah layak jual. Pengomposan merupakan teknik untuk mengolah sampah organik. Ada beberapa teknik mengolah sampah organik antara lain pengomposan, pembuatan briket dan biogas. Namun, teknik yang paling mudah dilakukan pada skala rumah tangga adalah mengubah sampah organik menjadi kompos. Pengomposan adalah proses penguraian terkendali bahan-bahan organik menjadi kompos yaitu bahan yang tidak merugikan lingkungan. Pada dasarnya sampah organik dapat terurai secara alami di alam, tetapi pada kondisi yang tidak dikontrol ini menyebabkan proses peruraian ini akan menimbulkan dampak lingkungan seperti lingkungan menjadi kotor, muncul bau tidak sedap, rembesan air lindi yang tidak terkendali dan lain sebagainya.

Pengomposan sampah organik dalam rumah tangga yaitu sampah sisa makanan, sisa potongan sayur dan buah serta sampah sapuan halaman dilakukan dalam alat yang disebut komposter. 
Kebutuhan komposter disesuaikan dengan jumlah sampah organik yang dihasilkan dalam suatu rumah tangga. Rumah yang mempunyai halaman luas dengan berbagai tanaman dapat menyediakan komposter dengan bentuk seperti pada Gambar 1.

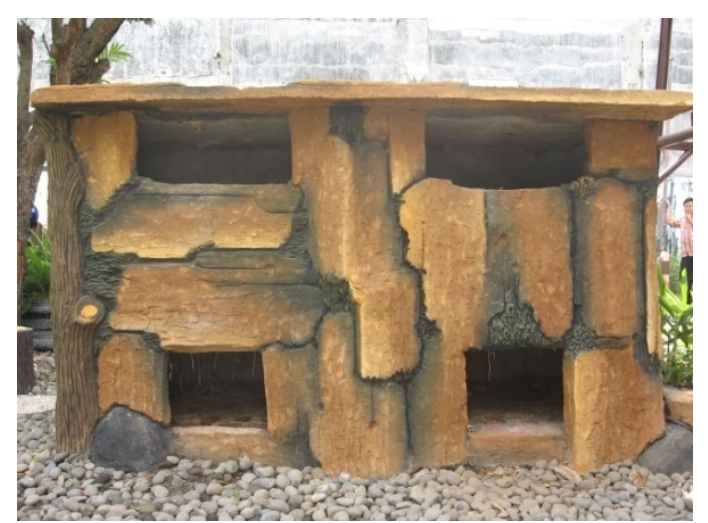

(a)

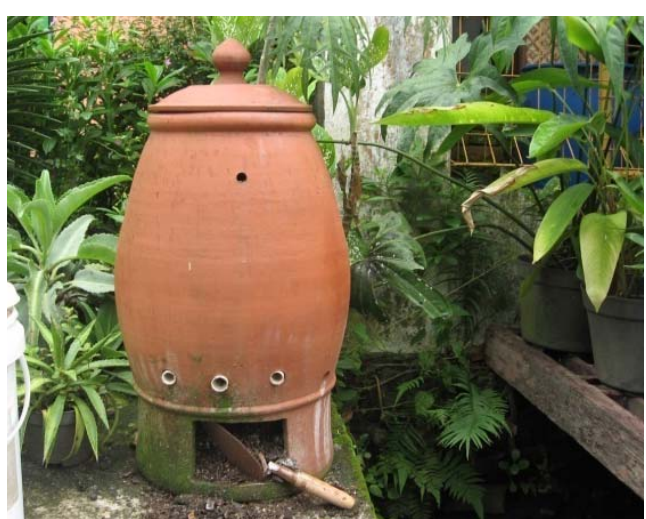

(b)

Gambar 1. Bentuk-bentuk Komposter yang cocok untuk Halaman Rumah (Iswanto, 2009)

Komposter (a) dapat disebut rumah kompos yang dapat menampung sampah sapuan halaman yang cukup banyak. Bangunan rumah kompos ini dibuat dari semen dan sifatnya permanen. Ukuran komposter dapat dibuat sesuai kebutuhan dan dapat diletakkan di salah satu sudut halaman sehingga dapat diakses dengan mudah. Namun apabila halaman rumah tidak terlalu luas atau sempit tetapi masih memungkinkan timbul sampah dedaunan maka komposter (b) yang sifatnya mudah dipindah ini sudah cukup mengakomodasi pengomposan sampah organik tersebut. Komposter ini juga cukup memadai untuk pengomposan sampah organik dari dapur. Bentuk komposter lain yang dapat digunakan untuk sampah organik dapur dapat dilihat pada Gambar 2.

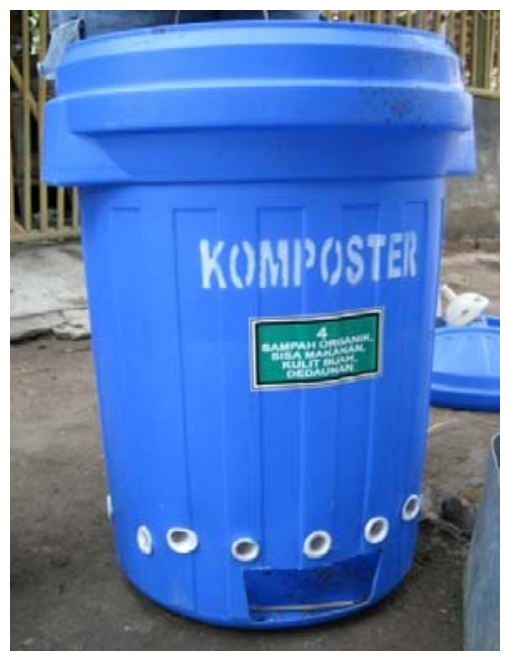

Gambar 2. Bentuk Komposter dari Bahan Plastik

Kompos yang dihasilkan dari pengomposan sampah organik dapat digunakan untuk memupuk tanaman yang dimiliki oleh rumah tangga sehingga selain sampah organik terolah tanaman juga tumbuh subur. Selain untuk menyuburkan tanaman, kompos ini juga dapat digunakan untuk 
menyuburkan tanah yang sudah kehilangan unsur hara akibat penggunaan pupuk anorganik. Menurut Murbandono (2008), salah satu unsur pembentuk kesuburan tanah adalah bahan organik (salah satunya kompos). Selain itu, pemanfaatan pupuk organik (kompos) untuk tanah sangat membantu memperbaiki struktur tanah, meningkatkan permeabilitas tanah, dan mengurangi ketergantungan bahan pada pupuk anorganik (Hadisuwito, 2008). Oleh karena itu, jika kompos yang dihasilkan dalam rumah tangga melebihi kebutuhan, maka kompos ini dapat dijual atau dibagikan kepada tetangga atau kolega yang membutuhkan manfaat dari kompos tersebut.

\section{- Pengelolaan Sampah Anorganik}

Pemilahan diawal ketika sampah timbul memudahkan proses pengelolaan sampah anorganik. Sampah anorganik rumah tangga secara umum dibagi menjadi plastik, kertas, kaca, logam, dan kain. Masing-masing sampah tersebut memiliki nilai jual karena sampah ini masih bermanfaat sebagai bahan daur ulang. Jika sampah organik rumah tangga dikelola secara mandiri (on site) dengan cara dikomposkan maka sampah anorganik harus dikelola dengan bantuan pihak ketiga (off site).

Pihak ketiga yang dapat mendukung pengelolaan sampah anorganik rumah tangga adalah para pelaku usaha daur ulang informal antara lain pemulung, tukang loak, lapak, bandar kecil dan bandar besar (Raihan dan Damanhuri, 2010). Selanjutnya Raihan dan Damanhuri (2010) dalam penelitiannya yang dilakukan di kota Bandung mengemukakan bahwa mata rantai perjalanan sampah dimulai dari pemulung yang akan menjual barang daur ulang ke pihak tukang loak. Selanjutnya pihak tukang loak akan menjual barang pada pihak lapak. Pihak lapak akan menjual barangnya kepada pihak bandar kecil dan bandar besar. Bandar besar adalah penampung terakhir yang menjual barangnya ke pabrik atau industri daur ulang. Pelaku usaha yang secara langsung dapat berinteraksi dengan pelaku pengelola sampah rumah tangga adalah pemulung dan tukang loak. Namun, tidak mustahil juga akan terjadi interaksi langsung antara pelaku pengelola sampah rumah tangga dengan lapak dan bandar kecil serta sebagian kecil bandar besar. Bandar besar pada umumnya hanya menerima pembelian dengan batasan berat minimal, namun ada juga yang menerima dari pelaku individu, loak maupun lapak.

Pihak ketiga lain yang saat ini sedang berkembang adalah bank sampah. Bank sampah merupakan salah satu sistem baru dalam mengelola sampah yang berkembang di Indonesia. Bank sampah adalah suatu wadah yang melakukan tiga kegiatan meliputi menghimpun sampah anorganik yang berpotensi untuk di daur ulang atau diubah menjadi bahan yang mempunyai nilai jual, menyalurkan bahan daur ulang dan produk dari sampah, dan melakukan bagi hasil dari hasil penjualan ke 
konsumen (Martono, 2011). Di Yogyakarta terdapat bank sampah di daerah Badegan Bantul yang saat ini menjadi pelopor berdirinya bank-bank sampah di daerah lain di Indonesia. Mekanisme bank sampah ini adalah melayani pengumpulan sampah anorganik daur ulang dari masyarakat, istilah yang digunakan adalah menambung sampah. Kemudian setelah terkumpul pihak bank akan menjual sampah ke pengepul (lapak atau bandar kecil) yang selanjutnya hasil penjualan diserahkan masyarakat kembali berdasarkan jumlah sampah yang telah ditabung. Keberadaan bank sampah ini tentu menjadi alternatif solusi dalam menangani sampah anorganik rumah tangga.

Pengelolaan sampah rumah tangga secara mandiri sangat bergantung pada keberadaan pihak ketiga ini di lingkungan sekitar rumah. Hal ini dikarenakan salah satu prinsip dari zero waste adalah pengumpulan barang layak jual. Sehingga setelah pengumpulan dilakukan terhadap sampah anorganik rumah tangga maka langkah selanjutnya adalah pemindahan sampah anorganik bernilai jual dari dalam rumah ke pihak ketiga yakni pemulung keliling, tukang loak atau bank sampah.

Ada perbedaan mendasar antara pemulung dengan tukang loak adalah pemulung dalam mencari barang daur ulang hanya bermodalkan karung sedangkan tukang loak bermodalkan gerobak yang memiliki daya tampung lebih besar (Raihan dan Damanhuri, 2010). Selain itu pemulung tidak membeli sampah daur ulang sedangkan tukang loak memiliki modal untuk membeli sampah daur ulang dari rumah tangga. Sehingga ada dua kemungkinan yaitu apabila sampah anorganik telah dikumpulkan dan dipindahtangankan ke pemulung maka pelaku pengelola sampah rumah tangga tidak mendapatkan nilai tambah secara ekonomi sedangkan bila dipindahtangankan ke tukang loak maka akan mendapatkan nilai tambah ekonomi. Namun dibandingkan dengan tukang loak, pemulung memiliki kelebihan yakni pemulung tidak memilih-milih sampah yang akan diangkut. Sedangkan tukang loak cenderung akan memilih barang yang benar-benar memberikan keuntungan sehingga sampah yang nilai jualnya sangat rendah tidak akan dibeli.

Lain halnya dengan bank sampah, pelaku pengelola sampah rumah tangga harus mendatangi lokasi bank tersebut untuk menabungkan sampahnya dan perlu sedikit usaha untuk mengangkut sampah. Namun, keadaan ini akan berbeda jika bank sampah tersebut sudah cukup maju sehingga melayani penjemputan sampah sehingga meringankan beban konsumen. Kelebihan bank sampah ini adalah banyaknya jenis sampah yang dapat ditabung dan adanya transaksi yang jelas sehingga konsumen mengetahui jumlah tabungan yang dimilikinya. Sedangkan kelemahannya adalah bank ini masih sangat sedikit jumlahnya sehingga sulit ditemui di lingkungan sekitar masyarakat. Namun, sebagai alternatif baru dalam penanganan permasalahan sampah, bank sampah ini memiliki peranan yang cukup besar dalam mengubah paradigma masyarakat tentang sampah yang selalu dikonotasikan dengan hal yang kotor dan bau menjadi sesuatu hal yang berkesan bernilai tinggi seperti bersih dan sistem yang teratur layaknya bank-bank pada umumnya. 
Hampir seluruh sampah anorganik memiliki nilai jual, hanya tinggi atau rendah harga biasanya tergantung beberapa faktor. Menurut Raihan dan Damanhuri (2010), faktor utama yang mempengaruhi fluktuasi harga rongsokan dari pabrik adalah permintaan konsumen akan barang olahan pabrik tersebut. Jika permintaan konsumen sedang tinggi, pabrik memerlukan banyak rongsokan untuk diolah menjadi bahan baku, sehingga harga rongsokan bisa naik. Sebaliknya, jika permintaan konsumen turun, pabrik jadi tidak memerlukan banyak rongsokan, sehingga harga turun. Bila kegiatan pembangunan ekonomi menurun, maka produksi, pendapatan, tabungan, dan investasi akan turun. Kegiatan perusahaan berkurang. Arus barang dan jasa berkurang. Sehingga menyebabkan kegiatan perdagangan berkurang, termasuk kegiatan perdagangan bahan potensial daur ulang.

Sampah rumah tangga yang terbesar volume sampahnya adalah plastik. Hal ini dikarenakan berkembangnya industri dan perubahan gaya hidup masyarakat mengarah pada konsumerisme menyebabkan plastik telah menjadi bagian dari gaya hidup masyarakat saat ini (Putra, 2010). Pada rumah tangga, sampah plastik yang sering dihasilkan adalah tas kresek, wadah atau botol kemasan produk seperti shampo, air mineral dan lain-lain serta plastik kemasan berlapis aluminium foil. Dari ketiga jenis plastik ini yang tidak memiliki nilai jual bagi pihak ketiga adalah plastik kemasan berlapis aluminium foil. Hal ini dikarenakan plastik ini tidak dapat dilebur karena adanya lapisan aluminium foil. Oleh karena itu, pengelolaan yang dapat dilakukan dilakukan pada sampah ini adalah dengan mendaur ulang menjadi kerajinan atau produk berguna. Gambar 3 memperlihatkan contoh dari produk hasil daur ulang sampah plastik kemasan berlapis aluminium foil.
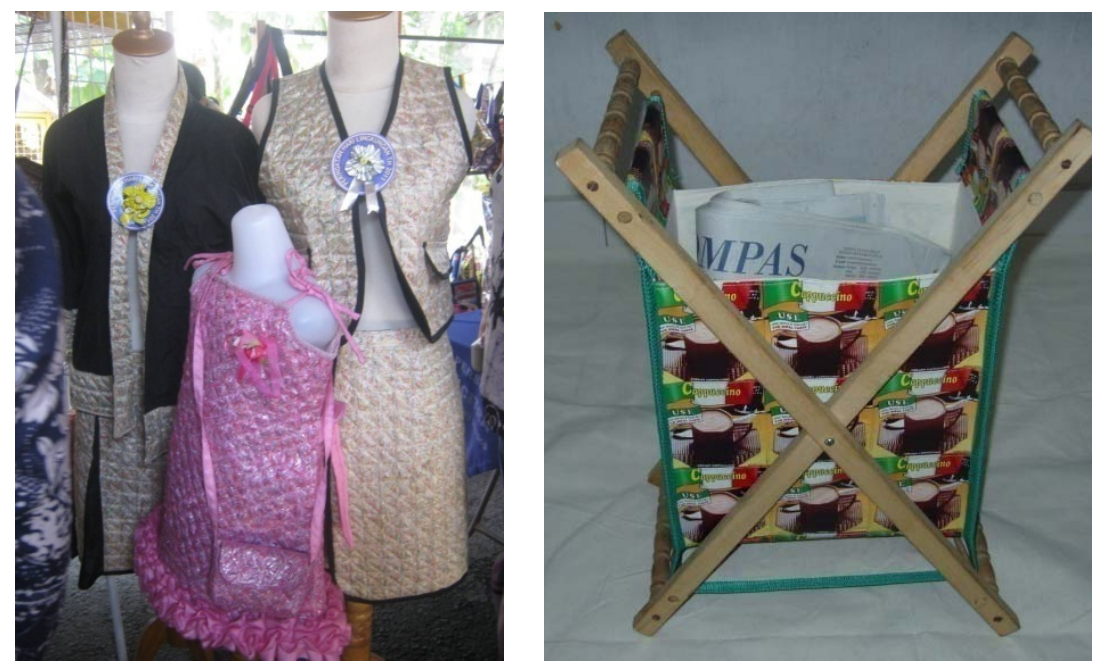

Gambar 3. Produk Daur Ulang Sampah Plastik Kemasan Berlapis Aluminium Foil

Peluang bisnis ini dapat dilakukan pelaku pengelola rumah tangga sendiri apabila ingin menambah penghasilan. Selain solusi sampah plastik kemasan berlapis aluminium foil terpecahkan, manfaat lain juga akan diperoleh yaitu munculnya usaha baru, meningkatnya pendapatan rumah tangga, 
membuka lapangan kerja baru serta pemberdayaan masyarakat secara ekonomi. Namun, untuk dapat mengolah sampah plastik kemasan menjadi produk daur ulang ini dibutuhkan keterampilan menjahit yang belum tentu dimiliki oleh pelaku pengelola rumah tangga. Oleh karena itu, untuk mengelola sampah ini juga dibutuhkan bantuan pihak ketiga yaitu dengan menjual sampah plastik kemasan berlapis aluminium foil kepada pengrajin produk daur ulang. Harga sampah ini umumnya lebih tinggi harganya daripada sampah anorganik lainnya karena harga sampah ini dihitung per lembar bukan per kilogram.

\section{- Pengelolaan Sampah B3 (Bahan Beracun dan Berbahaya)}

Sampah B3 merupakan salah satu komponen sampah yang akan dihasilkan dalam rumah tangga walaupun volumenya sangat rendah yaitu sekitar 2\% (Lia, 2009). Contoh sampah B3 ini antara lain batu batere, lampu bohlam/neon, wadah kemasan pembersih lantai, sisa racun tikus/serangga, sisa oli dan lain sebagainya.

Sampah B3 tidak dapat diolah atau dikelola oleh para pelaku daur ulang karena sampah B3 termasuk dalam sampah spesifik yang menurut UU No. 18 Tahun 2008 Tentang Pengelolaan Sampah, sampah spesifik adalah sampah yang karena sifat, konsentrasi, dan/atau volume memerlukan pengelolaan khusus. Sampah B3 ini tidak boleh dibuang secara langsung ke lingkungan tetapi harus dikelola oleh pihak yang berwenang seperti instansi terkait atau pelaku usaha pengolahan limbah B3 yang mengetahui cara mengolah sampah B3. Oleh karena itu, pelaku pengelola sampah rumah tangga hanya diwajibkan menyimpan sampah B3 selama maksimal 90 hari (Berdasarkan PP No. 18 Tahun 1999).

Pengelolaan sampah B3 yang dapat dilakukan dalam skala rumah tangga adalah menyimpan selama maksimal 90 hari kemudian sampah tersebut diangkut ke Tempat Pembuangan Sementara (TPS) terdekat untuk kemudian diangkut ke TPA oleh petugas kebersihan. Dalam menyimpan dan mengangkut sampah B3 perlu wadah yang ditandai khusus sehingga dapat diketahui oleh pengangkut sampah TPS.

\section{c) Aspek Sosial-Budaya Pengelolaan Sampah Secara Mandiri}

Pengelolaan sampah skala rumah tangga secara mandiri pada aspek teknis sangat mudah dilakukan. Berdasarkan uraian sebelumnya, pengelolaan sampah dengan konsep zero waste pada dasarnya tetap menerapkan prinsip Reduce, Reuse, Recycle (3R). Dan selanjutnya, skema pengelolaan sampah rumah tangga secara mandiri berdasarkan uraian tersebut sebagaimana terdapat pada Gambar 4. 


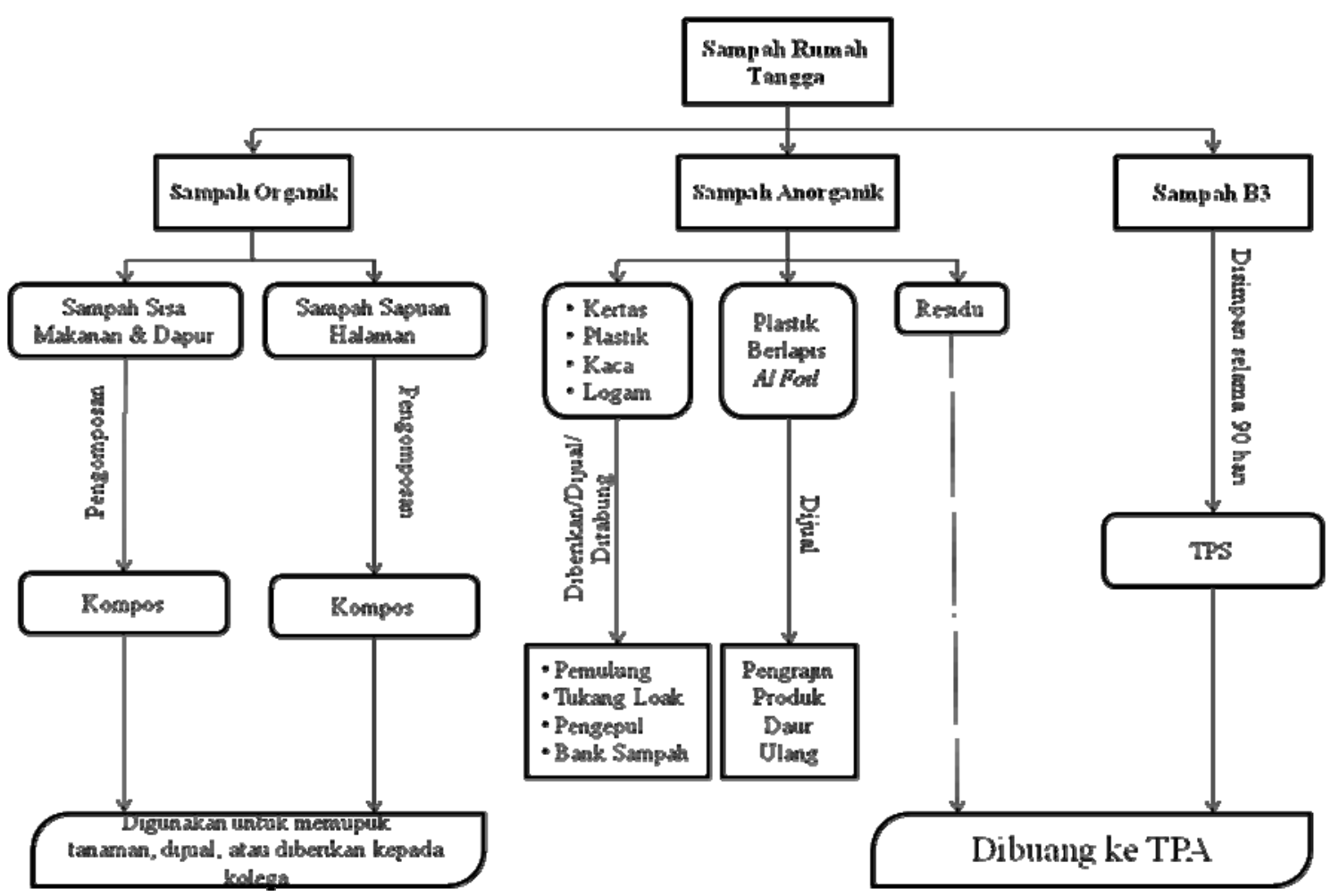

Gambar 4. Skema Pengelolaan Sampah Rumah Tangga Berbasis Zero Waste

Berhasil atau tidaknya konsep zero waste ini selain didukung aspek teknis yang jelas tentu juga harus didukung oleh aspek sosial-budaya pada masing-masing anggota keluarga. Pelaksanaan pengelolaan sampah dengan konsep zero waste pada rumah tangga pada umumnya diinisiasi oleh salah satu anggota keluarga yang bertindak sebagai agent of change (agen perubah). Agent of change terbentuk karena bertambahnya pengetahuan seseorang tentang lingkungan terutama mengenai dampak sampah terhadap lingkungan yang diperoleh dari luar rumah. Meningkatnya pengetahuan ini akan dapat memicu terbentuknya persepsi individu mengenai sampah dan pada akhirnya menimbulkan inisiatif untuk melakukan tindakan nyata menjaga lingkungan salah satunya yaitu mengelola sampah dalam rumah tangga. Tingkat pengetahuan memberikan kontribusi yang signifikan terhadap terbentuknya persepsi individu, sedangkan aksebilitas terhadap informasi, khususnya mengenai pemilahan dan daur ulang sampah, secara signifikan memberikan kontribusi terhadap persepsi individu dan partisipasi dalam pengelolaan sampah (Saribanon, 2009).

Menurut Saribanon (2009), selain sebagai agen perubah, inisiator juga akan berperan sekaligus sebagai block leader. Block leader adalah individu yang mengajukan dirinya secara sukarela (bekerja tanpa mendapatkan upah/pembayaran) untuk mendistribusikan informasi konservasi lingkungan. Jadi, individu inisiator selain memulai pelaksanaan pengelolaan sampah berbasis zero waste secara teknis, Ia juga mendelegasikan dirinya untuk menyebarluaskan informasi dan memotivasi anggota keluarga yang lain untuk melakukan pengelolaan sampah terutama dalam pemilahan sampah. 
Keberhasilan penyebarluasan informasi kepada anggota keluarga tergantung pada beberapa faktor. Menurut Utami (2008), faktor-faktor yang mempengaruhi partisipasi dalam pemilahan sampah rumah tangga adalah pendidikan, jenis kelamin, dan persepsi individu. Semakin tinggi pendidikan dan semakin baik persepsi seseorang terhadap kebersihan maka semakin tinggi pula kemampuan memilah sampahnya. Sehingga semakin banyak jumlah anggota keluarga yang berpendidikan tinggi maka semakin mudah informasi diterima oleh mereka. Jenis kelamin perempuan lebih tinggi kemampuan memilah sampahnya dibandingkan laki-laki. Apabila sebuah keluarga mempunyai jumlah wanita lebih banyak maka partisipasi akan semakin tinggi maka pelaksanaan pengelolaan sampah akan semakin baik. Pada akhirnya, pilihan cara pengelolaan sampah berbasis zero waste secara teknis terutama pada sampah layak jual, apakah akan diberikan ke pemulung; atau dijual ke tukang loak; atau ditabung di bank sampah, bukanlah inti dari pengelolaan sampah berbasis zero waste tetapi yang terpenting adalah kesadaran pada tiap individu bahwa sampah harus dikurangi masuk ke TPA atau tidak berada di tempat pembuangan liar sehingga kegiatan ini mampu menjadi ujung tombak mengatasi permasalahan sampah yang ada di Indonesia.

\section{Kesimpulan dan Saran}

a. Pengelolaan sampah rumah tangga berbasis zero waste secara mandiri diawali dengan melakukan pemilahan terhadap sampah; pengomposan terhadap sampah organik (basah) yang dihasilkan dan pengumpulan terhadap sampah anorganik layak jual.

b. Ada 3 cara alternatif untuk mengelola sampah anorganik yang layak jual yang sudah dikumpulkan yaitu diberikan kepada pemulung; dijual kepada tukang loak; atau ditabung di bank sampah.

c. Aspek sosial-budaya juga berperan dalam tercapainya pelaksanaan pengelolaan sampah berbasis zero waste secara mandiri yaitu adanya agent of change sekaligus block leader di dalam lingkungan rumah yang menyebarluaskan informasi dan memotivasi anggota keluarga yang lain untuk melakukan pengelolaan sampah terutama dalam pemilahan sampah.

\section{Daftar Pustaka}

El Haggar, Salah. (2007). Sustainable Industrial Design and Waste Management. Elsevier Academic Press: United States of America.

Hadisuwito, Sukamto. (2008). Membuat Pupuk Kompos Cair. AgroMedia Pustaka: Jakarta.

Ika, Dian. (2010). Pengelolaan Sampah Menuju Zero Waste di Kelurahan Kebonmanis Cilacap. http://eprints.undip.ac.id/4972/ diakses tanggal 10 Desember 2011. 
Iswanto. (2009). Model Pengelolaan Sampah Berbasis Masyarakat, Bahan Presentasi disampaikan pada Kursus Singkat Teknologi Pemanfaatan Sampah/Limbah di Magister Sistem Teknik Universitas Gadjah Mada, Yogyakarta.

Lya, T.K. (2009). Sampah Domestik Perkotaan. Bahan presentasi disampaikan pada Kunjungan Lapangan Mahasiswa Magister Sistem Teknik di Pusat Penelitian Dan Pengembangan Permukiman, Bandung.

Maharani, E.S., dkk. (2007). Karakteristik Sampah dan Persepsi Masyarakat Terhadap Pengelolaan Sampah di Kecamatan Banyuwangi Kabupaten Banyuwangi Provinsi Jawa Timur. Ecotropic, Vol. 2, No. 1, hal. 1-8 http://ejournal.unud.ac.id/abstrak/sinta\%20enggar\%20 maharani(1).pdf diakses 13 Februari 2012.

Martono, H.D., dan Bebassari, Sri. (2011). Bank Sampah, Bahan Presentasi disampaikan pada Rapat Kerja Teknis Bank Sampah di Jogjakarta Plaza Hotel, Yogyakarta.

Murbandono. (2008). Membuat Kompos. Penebar Swadaya: Jakarta.

Putra, H.P., dan Yuriandala Yebi. (2010). Studi Pemanfaatan Sampah Plastik Menjadi Produk dan Jasa Kreatif. Jurnal Sains dan Teknologi Lingkungan, Volume 2, No. 1. hal. 21-31.

Raihan, Cut., dan Damanhuri, Tri Padmi. (2010). Potensi Ekonomi Kegiatan Daur Ulang Sampah Tetrapak Kemasan Produk pada Sektor Informal di Kota Bandung. http://www.ftsl.itb.ac.id/kk/air.../PI-SW4-CUT-RAIHAN-15304035.pdf diakses tanggal 2 Januari 2012.

Saribanon, N., dkk. (2009). Perencanaan Sosial dalam Pengelolaan Sampah Permukiman Berbasis Masyarakat di Kotamadya Jakarta Timur. Forum Pascasarjana, Vol. 32 No. 32, hal 143 - 153 http://www.jurnal.pdii.lipi.go.id/admin/jurnal/32209143153.pdf diakses tanggal 13 Februari 2012.

Surbakti, S., dan Hadi, Wahyono. (2009). Potensi Pengelolaan Sampah Menuju Zero Waste yang Berbasis Masyarakat di Kecamatan Kedungkandang Kota Malang. http:// diakses 13 februari 2012.

Utami, D.B., dkk. (2008). Pengelolaan Sampah Rumah Tangga Berbasis Komunitas: Teladan dari Dua Komunitas di Sleman dan Jakarta Selatan. Sodality: Jurnal Transdisiplin Sosiologi, Komunikasi, dan Ekologi Manusia, April 2008, hal. 49-68 http://jurnalsodality.ipb.ac.id/jurnalpdf/edisi4-3.pdf diakses 13 Februari 2012. 